\title{
新疆北部石炭系大型火山岩风化体结构与 地层油气成藏机制
}

\author{
邹才能*，侯连华，陶士振，袁选俊，朱如凯，张响响，李富恒，庞正炼 \\ 中国石油勘探开发研究院, 提高石油采收率国家重点实验室, 北京 100083 \\ *E-mail: zcn@ @etrochina.com.cn
}

收稿日期: 2010-08-16; 接受日期: 2011-01-07

国家科技重大专项(批准号: 2008ZX05001, 2011ZX05001)和国家重点基础研究发展计划项目(编号: 2009CB219304)资助

\begin{abstract}
摘要新疆北部上石炭统发育于碰撞后松驰垮塌构造环境, 火山岩和烃源岩间互广泛分 布，石炭纪末受板块挤压整体抬升遭受风化淋滤，使火山岩不整合风化体形成 5 层结构，其 中溶蚀带和崩解带是有利储层发育段, 火山岩风化体发育于古地貌出露水面区, 低洼处和 斜坡带发育较完整的 5 层结构, 高部位一般缺失土壤层. 风化体厚度与风化淋滤时间呈正 向非线性指数关系, 风化体厚度动态平衡时间约为 $36.3 \mathrm{Ma}$, 最大风化体厚度约 $450 \mathrm{~m}$, 断 裂发育处风化体厚度更大, 长期风化淋滤区各种火山岩岩性均能形成风化体. 火山岩风化 体和烃源岩组合, 发育源内火山岩风化体层序型、源上火山锥风化体准层状和侧源火山岩 风化体梳状 3 种成藏模式, 均可形成大型火山岩风化体地层油气藏. 该认识改变了火山岩 油气勘探中寻找有利岩性和岩相带的传统模式, 修正了新疆北部石炭系为盆地基底, 不具 备油气生成条件的观点, 对指导火山岩风化体油气勘探具有重要的科学意义和应用价 值. 指出中国中西部古生界存在形成大规模火山岩风化体地层油气藏的条件, 是今后油气 勘探的新领域.
\end{abstract}

\section{关键词}

新疆北部

石炭系

火山岩风化体 地层油气藏

成藏机制与模式
近几年, 中国石油新增探明油气储量中地层油 气藏所占比例不断增加 ${ }^{[1 ~ 3]}, 2008$ 年占 $35 \%, 2009$ 年 占 $37 \%$, 特别是火山岩地层油气藏储量增加较快, 占 地层油气藏探明储量 $50 \%$ 以上(据国土资源部石油天 然气储量评审办公室数据), 火山岩地层油气藏已逐 步成为中国油气勘探的一个重要领域. 不整合面之 上受层序控制的碎屑岩地层油气成藏机制和分布规 律研究较多、相对较成熟 ${ }^{[4 \sim 6]}$, 国内外发现的火山岩 油气藏主要分布于中新生代原生型火山岩中, 储层
主要受岩性和岩相控制 ${ }^{[7 ~ 12]}$. 火山岩储集层已成为储 集层研究的前沿领域之一, 古生界及以下火山岩油 气藏发现较少, 对其研究主要集中于岩石学和年代 学 ${ }^{[13,14]}$. 新疆北部石炭系虽然在准噶尔盆地西北缘 发现火山岩油气藏, 但被一致认为是盆地双基底结 构的上层褶皱基底 ${ }^{[15]}$. 2005 年开始逐步在新疆北部 石炭系火山岩中发现了受火山岩风化体控制的自生 自储地层油气藏，但其控制因素和油气成藏机制不 清楚，限制了油气勘探的进一步扩展. 本文基于大量

英文引用格式: Zou C N, Hou L H, Tao S Z, et al. Hydrocarbon accumulation mechanism and structure of large-scale volcanic weathering crust of the Carboniferous in northern Xinjiang, China. Sci China Earth Sci, 2011, doi: 10.1007/s11430-011-4297-8 
实际资料的综合研究，提出新疆北部石炭系并非盆 地基底, 发育一套高磁性的火山混杂岩，揭示了火山 岩优质储层的成因机理和油气成藏机制, 提出了火 山岩风化体油气成藏新模式, 改变了新疆北部石炭 系为盆地基底, 不具备油气生成条件的认识, 扩大了 油气勘探领域.

\section{1 区域构造背景}

新疆北部及邻区大地构造奠基于中-新元古代 的塔里木板块、哈萨克斯坦板块与西伯利亚板块拼 合，主体属哈萨克斯坦构造域，此后又经历了复杂 大陆裂解-拼合 ${ }^{[16]}$, 于早石炭世末再次拼合为统一 大陆. 中-新元古代至石炭纪的板块构造演化过程大 致可分为板块拼合、大洋消减闭合、洋盆消减软碰 撞、陆-陆碰撞和碰撞期后伸展垮塌-板内变形 5 个阶 段 ${ }^{[17 ~ 19]}$. 早石炭世早期为碰撞间歇期伸展-残留海 闭合和陆-陆碰撞阶段, 是由于泥盆纪末期的快速聚 敛-软碰撞后, 构造应力场发生间歇性松弛, 并导致 深部热调整与岩浆活动所致; 早石炭世晚期为碰撞 期后伸展垮塌-板内变形作用阶段, 此时期聚敛-俯 冲作用逐渐强化, 并最终导致板块间发生强烈陆-陆 碰撞, 产生强烈的岩石变形, 形成显著的早海西期 褶皱带 ${ }^{[20]}$.

晚石炭世陆-陆碰撞后的垮塌裂陷为火山混杂岩 形成提供了条件, 普遍发育火山-沉积建造, 表现为 火山岩与沉积岩间互发育; 主要沿前期古缝合带附 近发育了一系列大型裂陷槽或裂陷海槽, 在地块内 部则发育了大型断陷带或裂陷带, 表现为火山-沉积

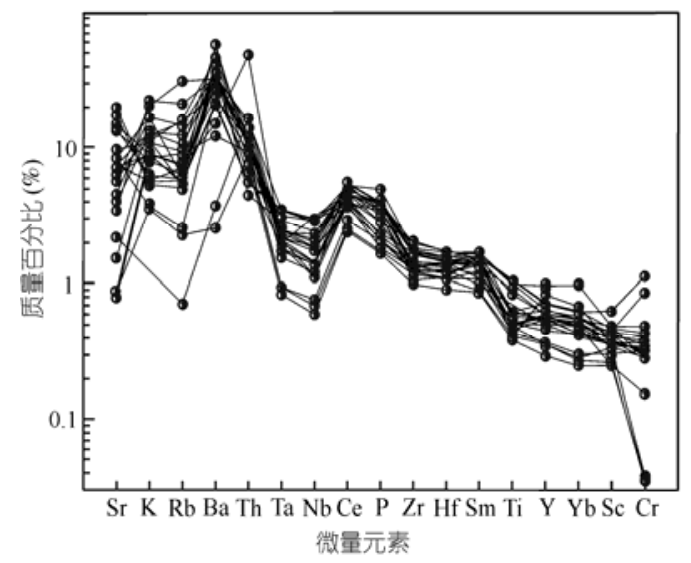

岩裂陷盆地. 火山岩具有双峰式特征, 主要为富钠玄 武岩和安山岩, 其次是流纹岩和英安岩. 玄武岩总体 上属于橄榄拉斑玄武岩, 并具有向碱性玄武岩和石 英拉斑玄武岩两个方向演化的趋势. 来自亏损地幔 的橄榄拉斑质玄武岩或苦橄榄岩浆经过分异并混杂 少量地壳物质的产物, 大部分属钻碱性系列, 少量为 碱性或拉斑玄武岩系列. 新疆北部盆地周缘广泛发育 了晚石炭世 $\mathrm{A}$ 型(或碱性)花岗岩与深断裂、蛇绿岩及 偏碱性的钾长花岗岩类紧密伴生, 呈带状分布 ${ }^{[21 ~ 26], ~}$ 这些是造山带伸展垮塌作用的典型标志，代表其应为 造山带伸展垮塌的构造环境.

新疆北部 20 口井钻遇石炭系火山岩样品分析结 果表明, 火山岩以碱性系列为主, 总体具有双峰式分 布特征，大离子亲石元素轻微富集的比值特征与板 内火山岩相似 ${ }^{[27]}$. 在稀土配分模式图上, 稀土总量较 高, 轻稀土为右倾富集型, 轻/重稀土分异明显. 在构 造环境判别图解上, 显示为板内环境. 火山岩反映了 地块内部的伸展裂陷构造环境(图 1).

\section{2 火山岩风化体成因机理及储层控制因素}

\section{1 火山岩岩性特征}

原生型火山岩储层主要发育于溢流相流纹岩和 爆发相角砾岩，酸性火山岩储层较发育，而中基性火 山岩物性较差，一般不能形成储层 ${ }^{[28]}$. 钻遇石炭系火 山岩的 57 口井 386 块岩心样品分析结果显示, 主要 岩石类型包括玄武岩、安山岩、火山角砾岩、凝灰岩 和流纹岩; 地球化学分析表明, 火山岩的 $\mathrm{SiO}_{2}$ 含量 在 $44 \% \sim 65 \%$ 之间，贫碱， $\mathrm{K}_{2} \mathrm{O}+\mathrm{Na}_{2} \mathrm{O}$ 含量一般小

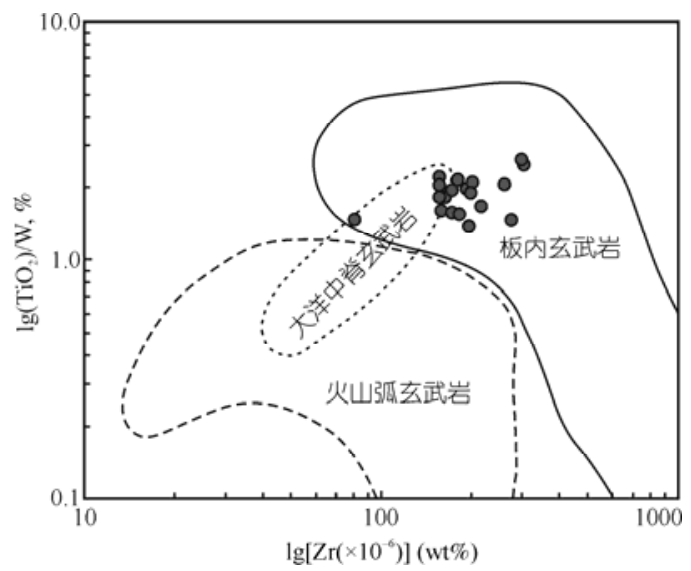

图 1 新疆北部火山岩微量元素及类型判别 
于 7.5\%, 在 TAS 图解中显示以中基性为主(图 2), 酸 性火山岩不发育。原生型火山岩一般不能形成有利 储层, 沉积间断的风化淋滤是新疆北部石炭系中基 性火山岩形成良好储层的主要控制因素.

\section{2 火山岩风化体结构特征}

以往对火山岩风化体的研究和勘探主要集中于 土壤层中次生矿产的分布, 对火山岩风化体储层、结 构及分布规律研究很少, 而火山岩风化体形成的储 层对油气聚集成藏起重要控制作用. 这里提出的火 山岩风化体是指火山岩风化后形成的具有矿物和储 层特征结构差异的联合体, 可通过岩心及微观照片 特征进行识别. 当钻遇火山岩顶部风化粘土层、火山 岩中断层处发育的氧化环境断层泥、自碎缝中氧化铁 衬边和火山岩粒内孔隙中存在示底构造等标志现象 时, 可判断为火山岩风化体.

通过对新疆北部石炭系火山岩 30 条野外露头剖 面和 78 口钻孔分析化验资料分析, 特别是对钻穿风化 体的 28 口井研究, 提出火山岩风化体完整的 5 层结构,
即土壤层、水解带、溶蚀带、崩解带和母岩(图 3). 土 壤层中多为次生矿物, 多数区域遭剥蚀, 成土状; 水 解带以泥岩和火山岩细小颗粒为主, 多数风化分解破 碎为泥土, 以蚀变作用为主; 溶蚀带中气孔杏仁构造 和裂缝发育，风化淋滤、构造碎裂和热液蚀变作用强; 崩解带以火山岩碎块为主, 块体较大, 见少量气孔, 微裂缝较发育, 裂缝和气孔被充填或半充填; 母岩中 火山岩块体完整, 孔洞缝不发育. 受表生环境地表水 淋滤和蒸发作用, 不同结构层中含盐量不同, 土壤层 中受蒸发作用影响含盐量较高; 水解带和溶蚀带是地 表水淋滤流经层, 含盐量较低; 崩解带位于风化体下 部, 为地表淋滤水的滞留层, 含盐量较高(图 4).

完整的火山岩风化体结构中土壤层、水解带、溶 蚀带和崩解带厚度所占比例分别约为 6\%, 24\%, $34 \%$ 和 $36 \%$. 低洼区具备完整 5 层结构, 坡度较陡的古构 造高部位一般缺失土壤层和水解带. 对 30 条野外露 头剖面测量和钻孔区古构造恢复, 发现土壤层分布 主要受控于(古)地貌坡度, 当古地貌坡度小于 $42^{\circ}$ 时 土壤层可连片分布，当古地貌坡度大于 $42^{\circ}$ 时局部发

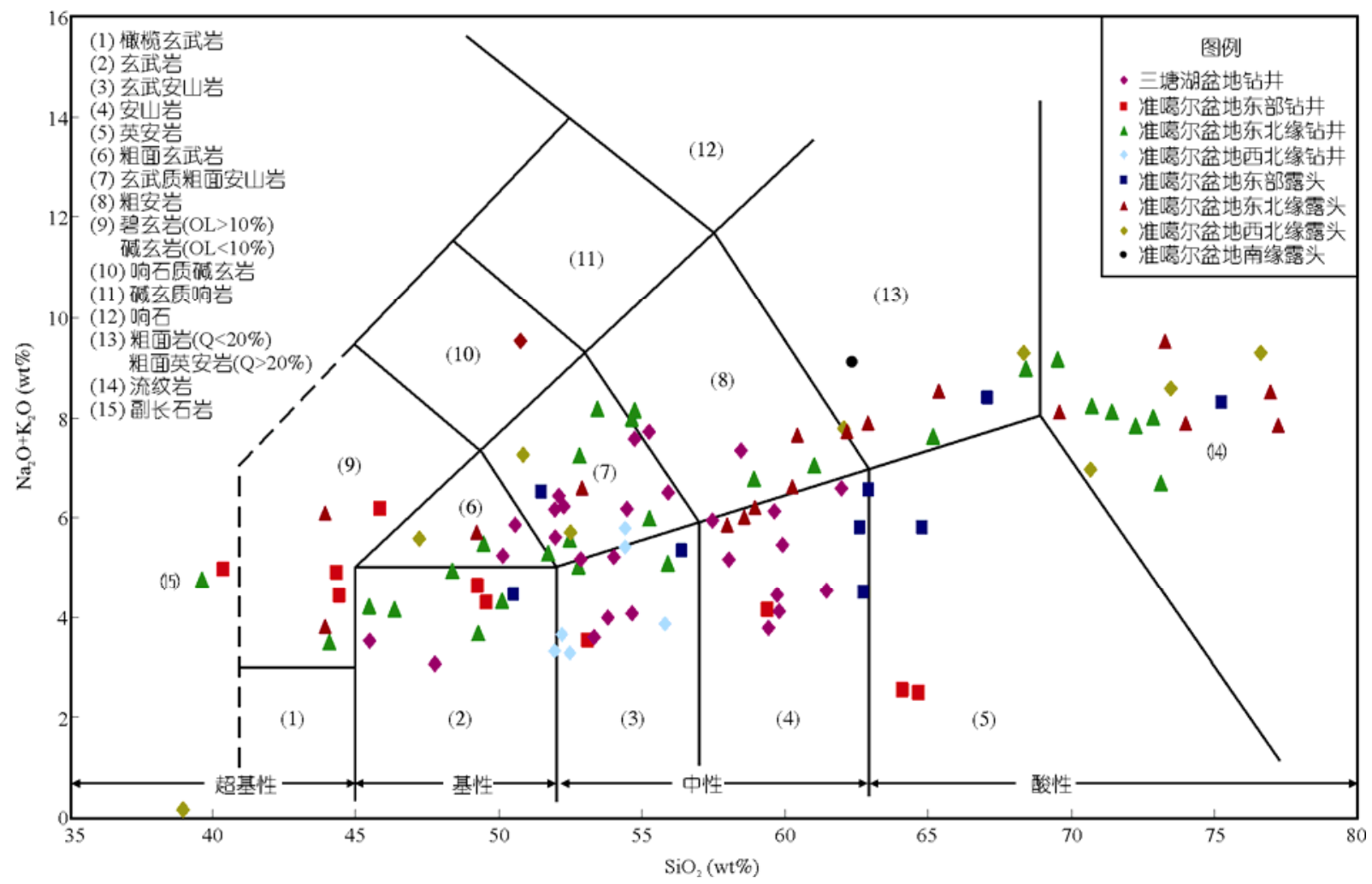

图 2 新疆北部石炭系火山岩化学成分 TAS 分类(据文献[29]) 


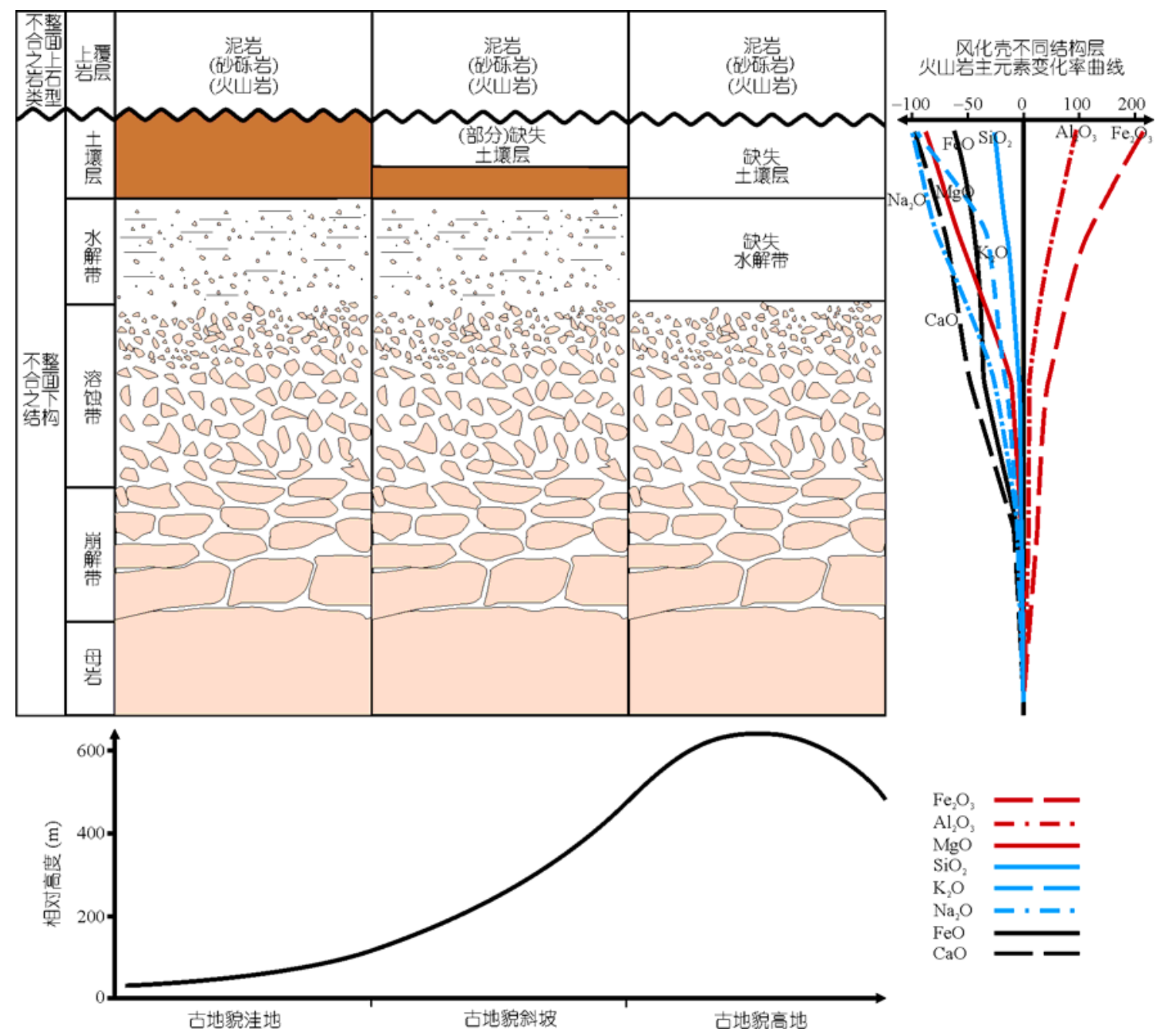

图 3 火山岩风化体结构

育土壤层. 古地貌洼地水流经区和构造应力集中的 古地貌陡峭区形成的土壤层厚度一般较薄, 对油气 遮挡和保存不利; 古地貌坡度较缓区土壤层大面积 分布为大型地层油气藏形成提供了有效遮挡条件.

在表生作用环境下火山岩中不同矿物的析出程 度和速度不同 ${ }^{[30,31]}$, 析出矿物被带走, 最易析出的元 素为 $\mathrm{K}^{+}, \mathrm{Na}^{+}, \mathrm{Ca}^{2+}$ 和 $\mathrm{Mg}^{2+}$ 等离子. 随着风化程度的加 强这些离子对应的 $\mathrm{K}_{2} \mathrm{O}, \mathrm{Na}_{2} \mathrm{O}, \mathrm{CaO}$ 和 $\mathrm{MgO}$ 等矿物逐 渐变少, 在土壤层中其含量很少, $\mathrm{SiO}_{2}$ 等矿物随着风 化程度的加强也有少量迁出 ${ }^{[32]}$, 由于可溶性较差, 在 土壤层中有一定的残存量; 随着氧化作用进行和矿 物转换, 氧化矿物在风化体中逐步富集, 如 $\mathrm{Al}_{2} \mathrm{O}_{3}$, $\mathrm{TiO}_{2}, \mathrm{Fe}_{2} \mathrm{O}_{3}, \mathrm{MgO}, \mathrm{P}_{2} \mathrm{O}_{5}$ 和 $\mathrm{FeO}$ 几乎全部变为 $\mathrm{Fe}_{2} \mathrm{O}_{3}$, 土壤层中其含量可以是火山岩母岩中的数倍. 不同
矿物的变化导致不同结构层的矿物成分存在差别, 颗粒大小和矿物成分的变化, 导致不同结构层的储 层物性存在很大差异(表 1). 对火山岩风化体储层物 性改变最大的是主元素变化量, 不同环境下发育的 火山岩主元素含量存在很大差别 ${ }^{[33,34]}$. 根据对新疆 北部石炭系火山岩 6 个完整风化体主要元素测定，提 出利用风化体不同结构中的所有主元素与同一风化 体母岩对应主元素含量的变化率之和确定风化程度, 即风化指数(式 1)来判断风化体不同结构界限. 火山 岩风化体土壤层、水解带、溶蚀带和崩解带的风化指 数判别标准分别为： $>50 \%, 25 \% \sim 50 \%, 10 \sim 25 \%$ 和 $<10 \%$ (表 1).

$$
\begin{gathered}
\mathrm{K}=\Sigma(\text { 母岩主元素含量-结构层主元素含量 }) / \\
\text { 母岩主元素含量 } \times 100 .
\end{gathered}
$$


表 1 三塘湖盆地石炭系火山岩风化体结构代表性样品主元素分析结果 ${ }^{\text {a) }}$

\begin{tabular}{|c|c|c|c|c|c|c|c|c|c|c|}
\hline \multirow{2}{*}{$\begin{array}{l}\text { 结构层 } \\
\text { 样品号 }\end{array}$} & \multicolumn{2}{|c|}{ 土壤层 } & \multicolumn{2}{|c|}{ 水解带 } & \multicolumn{2}{|c|}{ 溶蚀带 } & \multicolumn{2}{|c|}{ 崩解带 } & \multicolumn{2}{|c|}{ 母岩 } \\
\hline & ND-1 & ND-2 & ND-3 & ND-4 & ND-5 & ND-6 & ND-7 & ND-8 & ND-9 & ND-10 \\
\hline $\mathrm{SiO}_{2}$ & 46.43 & 47.47 & 49.63 & 51.43 & 52.63 & 55.34 & 54.29 & 55.78 & 55.4 & 56.67 \\
\hline $\mathrm{Na}_{2} \mathrm{O}$ & 0.01 & 0.02 & 0.68 & 0.93 & 1.92 & 2.21 & 2.41 & 3.28 & 2.74 & 3.73 \\
\hline $\mathrm{MgO}$ & 0.74 & 0.59 & 3.25 & 2.58 & 3.66 & 2.49 & 3.86 & 3.06 & 4.11 & 3.25 \\
\hline $\mathrm{Al}_{2} \mathrm{O}_{3}$ & 26.74 & 27.36 & 20.94 & 22.09 & 17.46 & 18.05 & 14.84 & 16.54 & 14.66 & 15.77 \\
\hline $\mathrm{P}_{2} \mathrm{O}_{5}$ & 0.45 & 0.57 & 0.51 & 0.4 & 0.39 & 0.28 & 0.36 & 0.29 & 0.26 & 0.21 \\
\hline $\mathrm{K}_{2} \mathrm{O}$ & 1.72 & 0.61 & 2.36 & 1.99 & 2.85 & 2.11 & 2.92 & 2.46 & 3.28 & 2.77 \\
\hline $\mathrm{CaO}$ & 0.05 & 0.03 & 1.38 & 1.48 & 2.47 & 2.65 & 4.21 & 4.51 & 4.94 & 5.3 \\
\hline $\mathrm{TiO}_{2}$ & 1.18 & 1.22 & 0.89 & 1.09 & 0.96 & 1.23 & 0.81 & 0.96 & 0.59 & 0.92 \\
\hline $\mathrm{MnO}$ & 0.09 & 0.16 & 0.08 & 0.15 & 0.08 & 0.15 & 0.08 & 0.14 & 0.08 & 0.14 \\
\hline $\mathrm{Fe}_{2} \mathrm{O}_{3}$ & 19.48 & 19.59 & 16.07 & 14.53 & 11.59 & 11.27 & 8.87 & 8.15 & 6.97 & 6.11 \\
\hline $\mathrm{FeO}$ & 2.52 & 1.72 & 3.45 & 2.36 & 5.12 & 3.49 & 6.45 & 4.39 & 6.64 & 4.53 \\
\hline 总量 & 99.41 & 99.34 & 99.24 & 99.03 & 99.13 & 99.27 & 99.1 & 99.56 & 99.67 & 99.4 \\
\hline $\mathrm{K}$ & 51.02 & 51.56 & 32.29 & 30.59 & 16.38 & 15.79 & 5.37 & 5.7 & 0 & 0 \\
\hline
\end{tabular}

a) 采用 ICP-AES 分析方法, 在西北大学地球动力学国家重点实验室完成, 主元素单位为\%

\section{3 火山岩风化体储层物性控制因素}

国内外发现的火山岩油气藏储层主要以未经中 长期风化淋滤或只经受火山喷发间歇期短暂风化淋滤 的原生型火山岩为主, 储层物性主要受岩相和岩性控 制 ${ }^{[28,35,36], ~}$ 爆发相中的火山角砾岩和溢流相中的流纹 岩储层物性较好, 平均孔隙度 $6 \%$ 11\%; 其他岩相和 岩性一般不能形成有效储层 ${ }^{[37]}$, 其产能主要受原始 储集空间控制 ${ }^{[38}$ 40]. 火山岩风化体与原生型火山岩 相比, 储层物性更好, 主要受风化体结构、风化淋滤 时间和裂缝等因素控制; 火山岩风化体中溶蚀带和 崩解带储层物性最好, 平均孔隙度 $10 \%$ 18\%, 能够 形成良好储层; 土壤层一般只能作为盖层; 水解带物 性差, 只能形成差储层. 以往油气勘探过程中没有认 识到火山岩风化体结构对储层物性的控制作用, 一 般钻遇火山岩风化体 $50 \mathrm{~m}$ 以内完钻. 在古构造高部 位或短期风化淋滤区, 由于土壤层和水解带较薄, 可 发现火山岩风化体地层油气藏; 而在长期风化淋滤 的古构造斜坡和低洼部位, 土壤层和水解带厚度一 般大于 $50 \mathrm{~m}$, 不整合面之下 $50 \mathrm{~m}$ 内储层物性较差, 导致勘探中的油气层漏失. 由于没有认识到断裂有 助于增加风化体厚度, 使得勘探深度不够, 漏失了深 层油气藏. 通过对新疆北部石炭系火山岩风化体及 油气藏解剖, 搞清了火山岩风化体有利储层的控制 因素, 为油气勘探深度选择提供了科学依据.

\subsection{1 火山岩风化体结构对储层物性的控制作用} 对新疆北部石炭系钻穿火山岩风化体的 28 口井,
不同结构层的 6854 个孔隙度分析样品系统分析, 其 结果是储层物性由好到差的顺序为溶蚀带、崩解带、 水解带、母岩和土壤层. 风化体结构从上到下的土壤 层、水解带、溶蚀带、崩解带和母岩的平均孔隙度分 别为 $2.6 \%, 5.4 \%, 16.8 \%, 12.7 \%$ 和 $4.6 \%$, 研究区火山 岩油气藏提交探明储量的孔隙度下限为 $6.4 \%$. 可见, 溶蚀带和崩解带能够形成有效储层, 是油气勘探的 主要目的层, 其他结构层和母岩不能形成有效储层. 其主要原因是不同结构层中孔隙结构的差异, 土壤 层以细喉微孔为主, 储层物性差, 一般作为盖层; 水 解带以细孔细喉为主, 储层物性较差, 钻探过程中会 见到油气显示, 但不能形成工业产能; 溶蚀带以中孔 粗喉为主, 溶蚀孔、洞和微裂缝发育, 储层物性最好, 一般具有双重介质特征, 已钻探的溶蚀带最大孔隙 度达 32\%, 试油结果同样证实溶蚀带是油气产出的 主力层段, 易形成高产油气层; 崩解带以细孔中喉为 主, 溶蚀孔和微裂缝较发育, 储层物性较好, 可形成 有效储层; 石炭系火山岩年代较老, 成岩作用较强, 母岩一般不能形成有效储层. 风化体不同结构层的储 层物性特征在勘探中得到证实, 如三塘湖盆地马 19 井火山岩风化体中溶蚀带、崩解带、水解带和母岩的 平均孔隙度分别为 $17.6 \%, 13.4 \%, 6.2 \%$ 和 4.8\%(图 4), 试油结果证实溶蚀带对应井段油产量最高.

\subsection{2 断裂对火山岩风化体储层物性的控制作用}

不整合是构造运动的产物, 构造运动使岩层发 生抬升变形的同时, 产生断裂和裂缝, 大断裂附近伴 


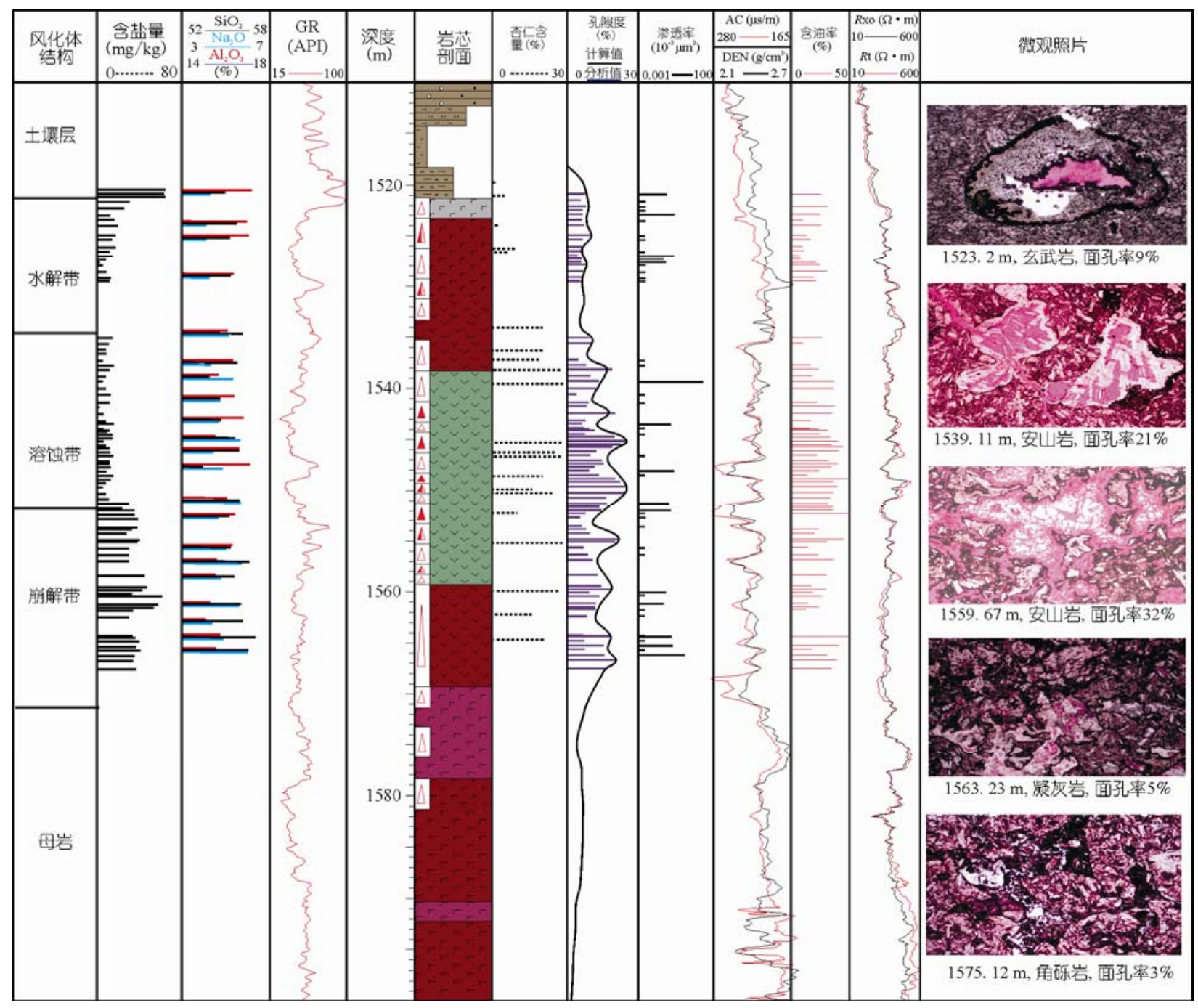

图 4 三塘湖盆地马 19 井石炭系风化体结构及储层物性特征

生次级小断裂，小断裂控制裂缝发育程度，断裂级别 越大控制的裂缝发育区范围越大. 裂缝发育控制了 储层质量. 如准噶尔盆地西北缘克-百断裂带上盘石 炭系火山岩, 距同一条断裂不同距离的取芯井岩芯 裂缝密度变化可见(图 5), 距离断裂越近裂缝密度越 大，距离断裂越远裂缝密度越小. 主断裂控制的 2 2.5 $\mathrm{km}$ 范围内是裂缝集中发育区, 多期构造运动使裂缝 交错成不规则网状，该区主断裂间隔 2 5 km，因此, 形成了整带具备形成有利储层条件的断裂与裂缝分 布格局. 在扎依尔山新鲜露头断层线附近存在低角 度斜交羽状裂缝，顺断层面常见宽窄不同的破碎带 和断层角砾岩. 钻井岩芯揭示, 断裂破碎带在同一口 井中可以多次出现, 破碎带的岩芯为碎块、角砾岩和

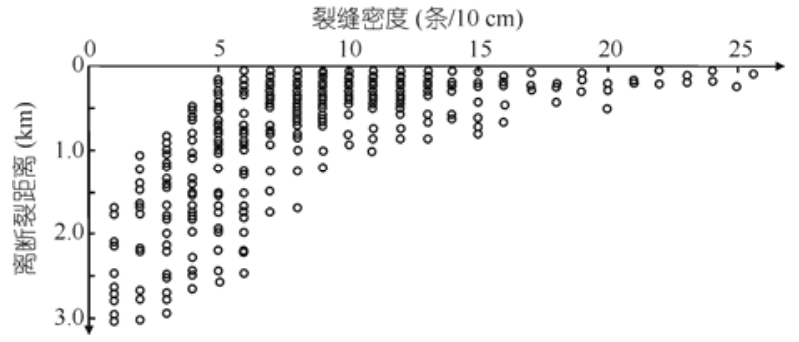

图 5 克-百断裂带上盘石炭系火山岩裂缝密度与断裂 距离的关系

断层泥等, 说明裂缝密度大. 不同火山岩岩性的力学 性质不同，相同条件下，不同岩性的裂缝发育程度 不同，如准噶尔盆地西北缘上盘石炭系克-百断裂带, 距离主断裂 $1 \mathrm{~km}$ 附近, 安山岩平均裂缝密度为 25 
35 条 $/ 10 \mathrm{~cm}$, 裂缝平均宽度 $0.6 \mathrm{~mm}$, 最大宽度可达 $3 \sim$ $5 \mathrm{~mm}$; 火山角砾岩裂缝密度为 $20 \sim 25$ 条/10 cm, 裂缝 平均宽度 $0.4 \mathrm{~mm}$, 最大宽度可达 $2 \sim 3 \mathrm{~mm}$; 玄武岩裂 缝密度为 $15 \sim 20$ 条 $/ 10 \mathrm{~cm}$, 裂缝平均宽度 $0.25 \mathrm{~mm}$, 最 大宽度可达 1 2 mm; 凝灰岩裂缝密度为 10 15 条/10 $\mathrm{cm}$, 裂缝平均宽度 $0.15 \mathrm{~mm}$, 最大宽度可达 $0.5 \sim 1 \mathrm{~mm}$.

断裂和风化体通常共存, 对储层改造具有叠加 性和互补性. 流体运移过程中, 断裂起垂向输导作用, 不整合面起横向输导作用, 两者结合使大气淡水、深 部热液和烃源岩热演化生成的酸性流体等在不整合 面之下地层中形成良好的循环系统, 使断裂附近火 山岩溶蚀更强, 断裂和裂缝沟通的区域可形成有利 储层, 使得风化体厚度大大扩展. 如准噶尔盆地西北 缘上盘石炭系经历了 $84 \mathrm{Ma}$ 的沉积间断，风化淋滤时 间、断裂断距和级次控制风化体厚度, 断距越大风化 体厚度越大, 风化体厚度最大可达 $1300 \mathrm{~m}$ (古 113 井); 断裂不发育处风化体厚度一般为 150 450 m. 准噶尔 盆地西北缘油源充足, 油层厚度受风化体厚度控制, 油层跨度范围 150 1300 m, 如远离断裂的克 108 井 油层跨度 $256 \mathrm{~m}$, 近主断裂的古 3 井油层跨度 $1290 \mathrm{~m}$, 近次级断裂的检 188 井区油层跨度 $756 \mathrm{~m}$. 沿断裂的 风化淋滤可穿越火山岩间的沉积岩夹层, 对夹层之 下的火山岩进行溶蚀. 三叠系夹层之下的火山岩在 裂缝发育区同样经受了风化淋滤形成有利储层并成 藏, 如 417 井两层试油分别日产油 40 和 $44 \mathrm{t} / \mathrm{d}$ (图 6).
在油气勘探中沿风化体顶面勘探的同时, 纵向断裂 带附近和断裂控制区域同样是有利勘探区, 这是以 前勘探中没有注意到的新领域.

\section{4 火山岩风化体厚度成因机制}

岩石风化主要受控于风化淋滤时间和表生环 境 ${ }^{[41 ~ 43]}$. 新疆北部石炭系沉积后的间断期处于干旱半干旱的亚热带气候, 风化体厚度主要取决于风化 淋滤时间. 利用新疆北部石炭系钻遇完整风化体结 构且有取芯的 28 口钻孔资料和两条野外剖面系统取 样研究, 揭示了风化体形成、剥蚀速度与厚度的关系.

前人通过野外砾石风化层计算确定研究区经历 的风化淋滤时间 ${ }^{[44 \sim 47]}$, 指出随风化淋滤时间延续, 砾石风化层厚度增大的速率逐渐变小, 在某个时间, 二者必然趋于动态平衡, 风化残余物厚度与风化淋 滤时间存在指数关系 ${ }^{[42,43]}$, 该关系仅适用于风化剥 蚀时间小于 $5000 \mathrm{a}$ 的情况下, 而新疆北部石炭系风 化淋滤时间远大于该时间, 该方法不适用于该区火 山岩风化体的研究. 借鉴前人砾石风化层研究经验 对火山岩风化体成因机制开展研究, 通过风化体残 余物形成和剥蚀速率关系推导、钻孔和野外剖面测量 以及风化淋滤时间恢复, 提出风化体厚度与风化淋 滤时间存在正向非线性指数关系.

风化残余物形成速率与风化淋滤时间存在负向 指数关系, 即随着风化体厚度增大, 残余物形成速率

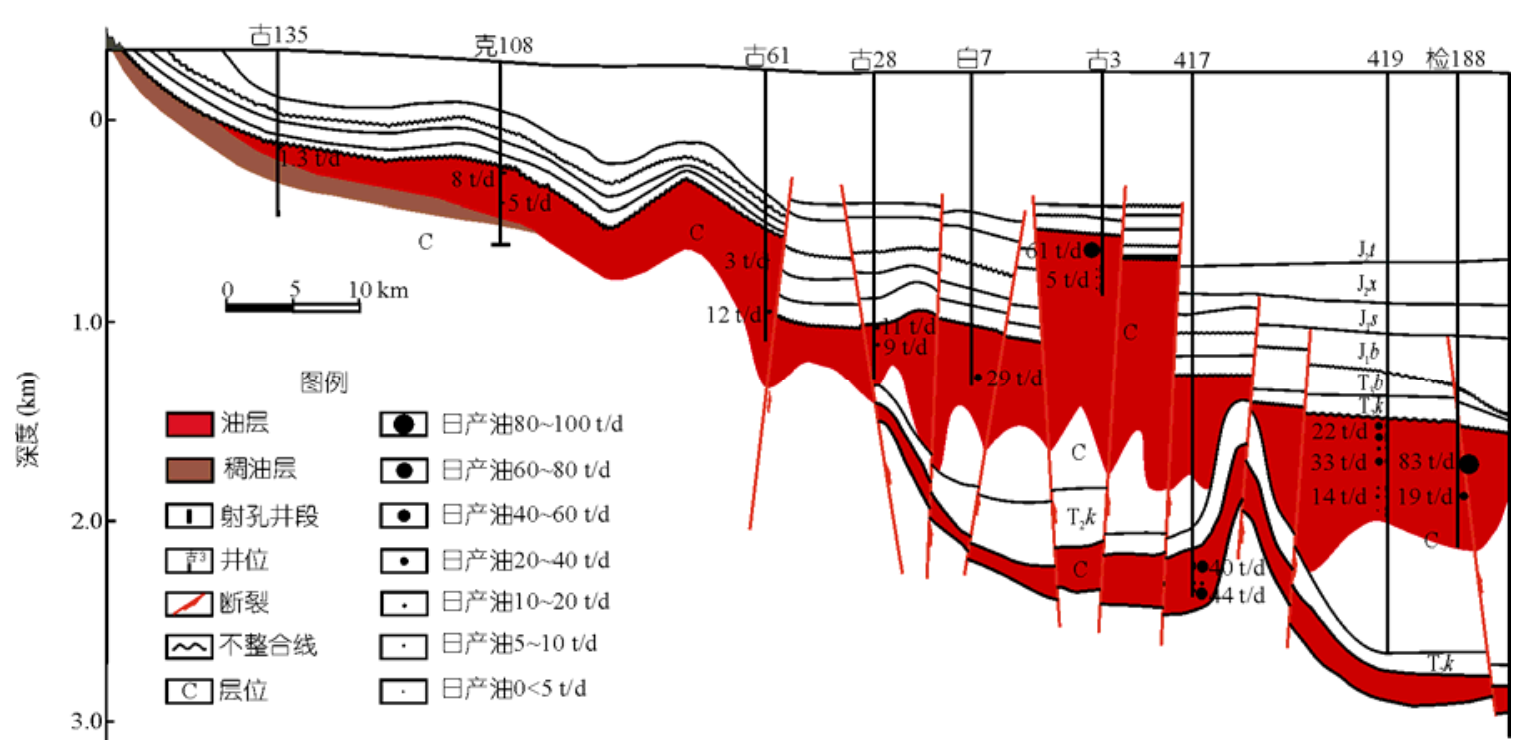

图 6 准噶尔盆地西北缘断裂带上盘石炭系火山岩风化体地层油藏剖面 
减小.

$$
\mathrm{d} r_{f} / \mathrm{d} t=k_{1}\left(r_{f}\right)^{-n_{1}},
$$

式中, $\mathrm{d} r_{f} / \mathrm{d} t$ 为风化残余物形成速率; $k_{1}$ 和 $n_{1}$ 是与岩性 和表生环境有关的参数, 均大于 0 .

风化残余物破坏速率随残余物厚度增加而增大, 二者之间存在正向指数关系:

$$
\mathrm{d} r_{d} / \mathrm{d} t=k_{2}\left(r_{d}\right)^{n_{2}},
$$

式中, $\mathrm{d} r_{d} / \mathrm{d} t$ 为风化残余物破坏速率; $k_{2}$ 和 $n_{2}$ 是与岩性 和表生环境有关的参数, 均大于 0 .

当外部因素保持在某一变化范围内时, 风化体 形成速率随风化淋滤时间增大而减小, 而剥蚀速率 随风化淋滤时间增大而增大. 当风化残余物形成速 率等于剥蚀速率时, 即 $\mathrm{d} r_{f} / \mathrm{d} t=\mathrm{d} r_{d} / \mathrm{d} t$, 风化体厚度趋 于最大. 这里风化剥蚀速率的确定不考虑断裂作用.

为了建立风化体厚度与风化淋滤时间关系模型, 首先确定风化淋滤时间, 即火山岩风化体与上覆地 层年龄之差. 现今认为火山岩年龄测定最准确的方 法是锆石测年, 选取风化体上部同一次火山喷发形 成的火山岩 3 个样品锆石年龄测定的平均值作为火 山岩风化体年龄. 风化体上覆地层为碎屑岩时, 其年 龄的确定采用同位素方法, 与火山岩锆石测年相比 测定误差较大. 在研究中采用了同位素测年、古生 物、岩性、地震和测井等共同确定方法, 首先通过同 位素测年、钻井、测井、岩性和古生物确定风化体上 覆地层的年代, 根据测井标定地震确定该套地层平
面上的厚度变化，与古地貌结合进一步将年代细分. 根据整合区同一套地层厚度及与古地貌的关系将风 化体上覆地层的年代控制在一定误差范围之内, 取 火山岩和上覆地层的平均年龄之差作为风化淋滤时 间. 采用该方法对 28 口钻遇火山岩完整风化体的钻 孔资料和 2 条野外露头实测剖面的计算得到风化体 厚度与风化淋滤时间(表 2), 从风化体厚度与风化淋 滤时间关系(图 7(a)) 可见, 安山岩、花岗岩、玄武岩、 火山角砾岩和凝灰质火山角砾岩等不同岩性随风化 淋滤时间的变化存在差别, 但是差别较小, 不同火山 岩岩性可以做统一考虑, 但凝灰岩一般不能形成风 化体, 风化体厚度与风化淋滤时间呈对数关系, 二者 关系模型见式(4):

$$
d=a \ln t+b,
$$

式中, $d$ 为风化体厚度 $(\mathrm{m}) ; t$ 为风化淋滤时间 $(\mathrm{Ma}) ; a$ 和 $b$ 为常数. 新疆北部石炭系火山岩 $a=81.427, b=$ 101.81 , 相关系数 $R^{2}=0.9756$.

当风化体厚度增加速率小于风化淋滤初期增加 速率的 5\% 时, 认为风化体厚度趋于动态平衡, 风化 体厚度趋于最大值, 形成的地层圈闭的储层厚度趋 于最大；火山岩达到风化淋滤平衡所需时间约为 $36.3 \mathrm{Ma}$ ，火山岩风化体厚度达到 50\%所需风化淋滤 时间约为 $5 \mathrm{Ma}$, 风化淋滤趋于平衡时的风化体平均 厚度约为 $450 \mathrm{~m}$. 利用此模型, 在确定研究区风化淋 滤时间后，可以预测火山岩风化体厚度，从而确定钻

\begin{tabular}{|c|c|c|c|c|c|c|c|}
\hline 井号 & 岩性 & $\begin{array}{c}\text { 风化淋滤时间 } \\
(\mathrm{Ma})\end{array}$ & $\begin{array}{c}\text { 风化体厚度 } \\
(\mathrm{m})\end{array}$ & $\begin{array}{c}\text { 井号/野外 } \\
\text { 剖面 }\end{array}$ & 岩性 & $\begin{array}{c}\text { 风化淋滤时间 } \\
\text { (Ma) }\end{array}$ & $\begin{array}{c}\text { 风化体厚度 } \\
(\mathrm{m})\end{array}$ \\
\hline G62 & 安山岩 & $71.5 \pm 3.73$ & 455 & G48 & 凝灰质角砾岩 & $74.5 \pm 3.68$ & 458 \\
\hline G65 & 安山岩 & $71.9 \pm 2.75$ & 451 & M17 & 玄武岩 & $0.52 \pm 1.26$ & 40 \\
\hline CF031 & 安山岩 & $108 \pm 5.43$ & 445 & M19 & 玄武岩 & $0.56 \pm 1.17$ & 73 \\
\hline SQ061 & 安山岩 & $3.2 \pm 1.12$ & 141 & ND8-3 & 玄武岩 & $0.35 \pm 1.12$ & 35 \\
\hline $\mathrm{SX} 1$ & 安山岩 & $46 \pm 2.9$ & 350 & M29 & 玄武岩 & $0.22 \pm 1.16$ & 25 \\
\hline XQ2 & 安山岩 & $27 \pm 1.7$ & 405 & ND9-10 & 玄武岩 & $0.77 \pm 1.19$ & 56 \\
\hline DX18 & 花岗岩 & $35 \pm 2.15$ & 402 & ND8-5 & 玄武岩 & $0.58 \pm 1.11$ & 49 \\
\hline D104 & 火山角砾岩 & $48 \pm 1.74$ & 458 & ND8-8 & 玄武岩 & $0.61 \pm 1.14$ & 70 \\
\hline 429 & 火山角砾岩 & $71 \pm 2.32$ & 436 & M36 & 玄武岩 & $0.55 \pm 1.18$ & 29 \\
\hline C55 & 火山角砾岩 & $2.1 \pm 1.24$ & 92 & ND103 & 玄武岩 & $1.32 \pm 0.71$ & 148 \\
\hline K111 & 火山角砾岩 & $70.2 \pm 2.43$ & 420 & M704 & 玄武岩 & $0.98 \pm 0.96$ & 109 \\
\hline DX14 & 凝灰质角砾岩 & $37 \pm 2.82$ & 428 & Ch24 & 玄武岩和火山角砾岩 & $106 \pm 3.32$ & 460 \\
\hline G59 & 凝灰质角砾岩 & $72 \pm 3.45$ & 469 & 野外剖面 1 & 火山角砾岩 & $4.7 \pm 0.83$ & 217 \\
\hline G94 & 凝灰质角砾岩 & $72.1 \pm 3.21$ & 441 & 野外剖面 2 & 安山岩 & $36.3 \pm 2.25$ & 432 \\
\hline
\end{tabular}
井设计深度. 在达到风化淋滤动态平衡前下沉埋藏

表 2 新疆北部石炭系不同火山岩岩性钻孔、野外露头剖面风化体厚度与风化淋滤时间的关系 ${ }^{\text {a) }}$

a) 风化体厚度包括土壤层、水解带、溶蚀带和崩解带的累积厚度之和 


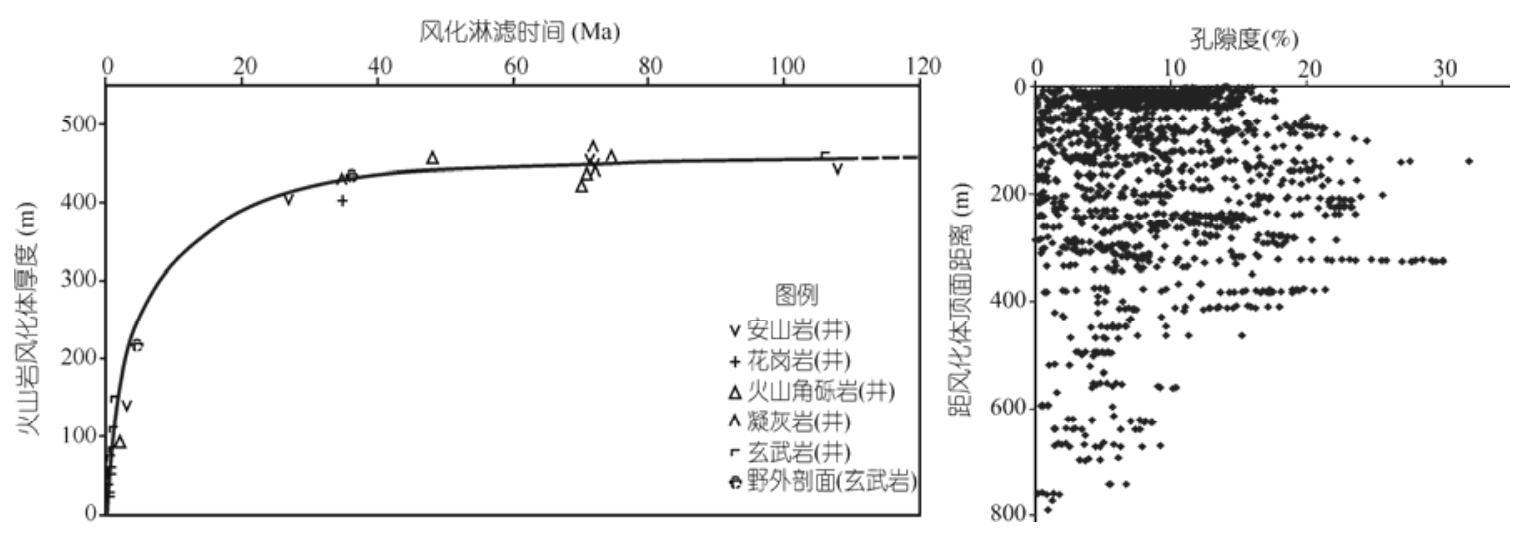

图 7 火山岩风化体厚度与风化淋滤时间和埋藏深度的关系

(a) 不同火山岩岩性风化体厚度与风化淋滤时间的关系; (b) 孔隙度随风化体顶面埋深分布

形成的地层圈闭，风化体厚度和规模要相对较小，因 此, 形成大规模火山岩风化体地层圈闭的控因之一 是风化淋滤时间超过一定值. 从钻遇石炭系火山岩 风化体取芯井孔隙度样品分析结果来看, 距主断裂 较远的风化体有利储层主要分布于风化体顶面以下 $450 \mathrm{~m}$ 的范围之内(图 7(b)), 这一点佐证了风化体厚 度与风化淋滤时间关系模型.

\section{3 火山岩风化体油气成藏机制与模式}

中国东西部火山岩成藏条件存在很大差别 ${ }^{[48]}$. 新疆北部石炭系发育火山混杂岩, 经构造和风化淋 滤改造, 火山岩形成了以风化淋滤为主的火山岩风 化体储层, 位于其内、下和侧缘的烃源岩生成的油气 在其中聚集成藏形成火山岩风化体地层油气藏. 已 发现克拉美丽、牛东、五彩湾、克拉玛依、车排子和 石西等 30 个油气田. 对 24 个火山岩风化体油气藏解 剖, 揭示了油气受纵向断裂和横向风化体联合输导, 在构造高部位聚集成藏, 建立了源内火山岩层序型、 源上火山雉准层状和侧源火山岩不整合梳状 3 种成 藏模式.

\section{1 源内火山岩层序型成藏机制与模式}

火山岩风化体储层在水体频繁震荡区发育，暴 露于水面之上的风化淋滤时间较短的火山岩风化体 与之后发育的烃源岩间互分布, 火山岩风化体受层 序界面控制, 烃源岩生成的油气直接或通过断裂运 聚在附近的火山岩风化体地层圈闭中成藏, 该类成 藏模式形成的地层型油气藏规模受控于风化体大小
和厚度，有效烃源岩覆盖区的风化体均可能成藏. 如 三塘湖盆地马朗凹陷石炭系, 频繁喷发的火山岩与 烃源岩互层, 火山喷发时火山堆积物露出水面, 火山 喷发间歇期火山岩遭受风化淋滤形成风化体，随着 沉积物加厚和水体变深, 火山岩风化体逐渐被水淹 没, 之上沉积了烃源岩. 石炭系内部发育多个这样的 组合, 从图 8 地震剖面上清楚可见火山岩与烃源岩互 层发育, 当烃源岩成熟后生成的油气沿断裂纵向运 聚于风化体内形成由多个风化体组成的纵向叠加和 平面连片的火山岩地层油藏. 上石炭统卡拉岗组内 部存在 5 个受层序控制的火山岩风化体成藏组合, 均 可发育地层油藏, 之下的哈尔加乌组烃源岩生成的 油气沿断裂纵向运聚于风化体内, 断裂发育处储层 更发育, 油气主要集中分布于断裂附近的火山岩风 化体内; 哈尔加乌组火山岩与烃源岩互层, 烃源岩生 成的油气沿断裂或直接运聚于火山岩风化体内聚集 成藏(图 8). 该区已探明石油地质储量 $5 \times 10^{7} \mathrm{t}$, 三级 石油地质储量近 $2 \times 10^{8} \mathrm{t}$, 是中国已发现受层序控制 的最大火山岩风化体层状地层油藏.

\section{2 源上火山雉准层状成藏机制与模式}

火山岩与烃源岩近水平间互分布，地层沉积后 受构造运动控制发生倾斜, 沿古地貌顶面发生风化 淋滤和剥蚀, 形成沿顶面火山岩风化体储层和沉积 岩(凝灰岩)非储层间互，后期下沉接受上覆沉积泥岩 覆盖形成以火山岩风化体为单元的地层圈闭, 当埋 藏到一定深度烃源岩成熟后, 烃源岩生成的油气通 过断裂或直接运移聚集于风化体地层圈闭中成藏. 这种成藏模式要求在不整合面形成后再次埋藏, 其 

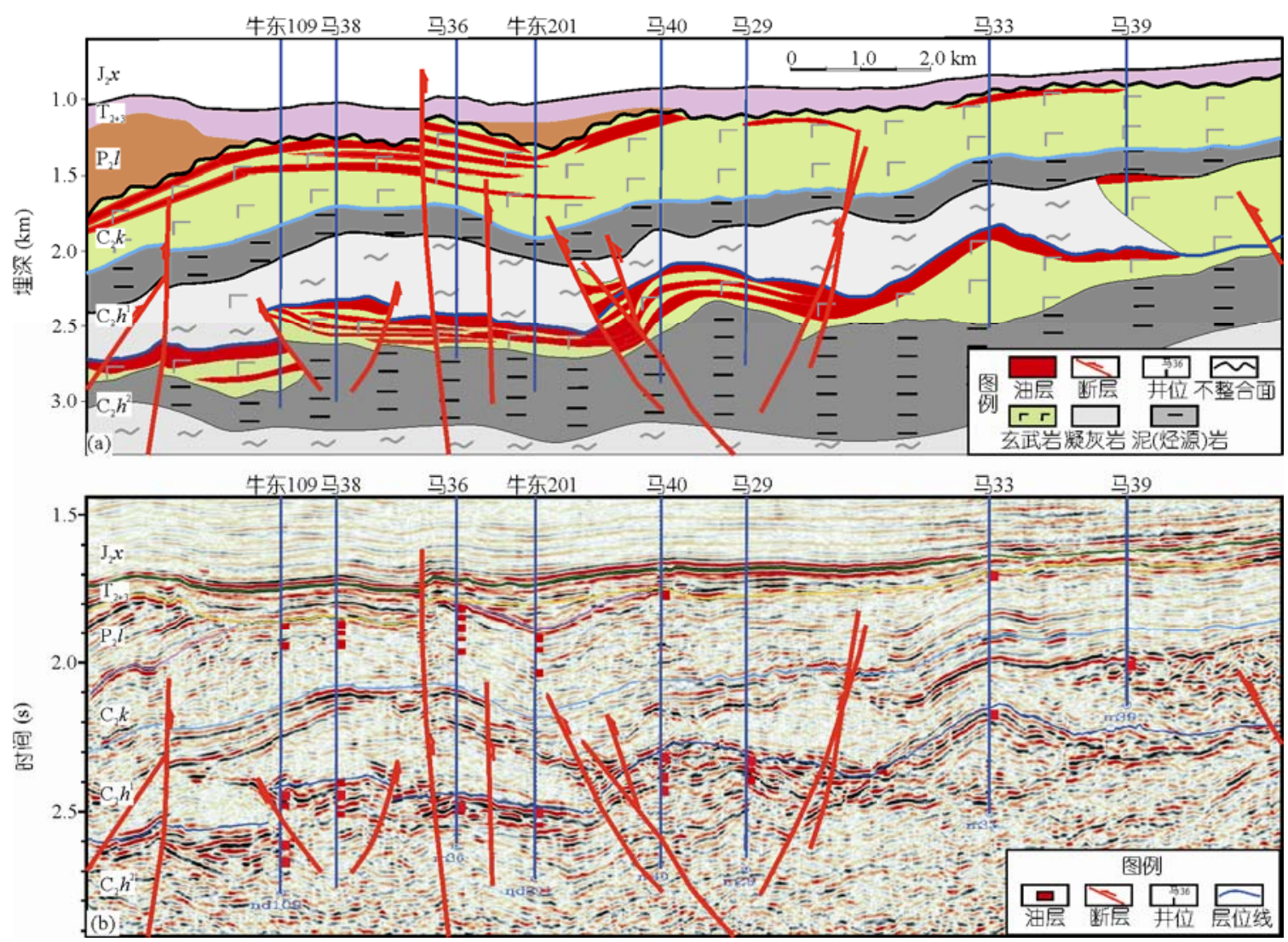

图 8 三塘湖盆地石炭系源内火山岩层序型成藏模式

(a) 油藏剖面; (b) 地震剖面

下烃源岩仍具有生烃能力, 油气藏规模受控于火山 岩风化体地层圈闭规模和油气聚集量, 风化体厚度 控制着火山岩风化体地层圈闭纵向规模, 火山岩风 化体平面规模控制地层圈闭大小，根据风化体、正向 构造和有效烃源岩条件耦合确定该类成藏模式有利 区. 如准噶尔盆地陆东上石炭统巴山组, 火山岩风化 体与烃源岩间互分布(图 9), 气藏沿石炭系顶面火山 岩风化体分布, 侧向受非渗透岩性遮挡，上面受土壤 层和上覆新地层泥岩遮挡, 各气藏之间不连通, 气藏 厚度受风化体厚度控制, 一般在 100 350 m 之间. 由 于生烃凹陷主要位于倾斜地层的下倾方向, 沿油气 来源方向在上倾部位的有效火山岩风化体地层圈闭 均有可能形成这类油气藏. 受近源成藏控制, 高部位 有效圈闭不一定充满, 或不成藏, 如距烃源岩较远的 滴西 24 井气藏高度 $78 \mathrm{~m}$; 距烃源岩和断裂匹配越近 的圈闭中油气充满度越高, 如距烃源岩和断裂较近 的滴西 18 井气藏高度 $258 \mathrm{~m}$, 最有利的火山岩风化 体油气藏主要分布于古构造的斜坡部位. 该区已探
明天然气地质储量超过千亿方, 是中国发现的最大 火山岩风化体准层状地层气藏.

\section{3 侧源火山岩不整合梳状成藏机制与模式}

前陆盆地发育区，火山岩受逆冲推覆作用抬升 接受长期风化淋滤, 沿不整合顶面和断裂发育处形 成梳型有利储层, 受后期沉积地层覆盖形成大型火 山岩风化体地层圈闭, 位于火山岩风化体地层圈闭 侧翼低部位的烃源岩生成的油气，通过断裂纵向运 移, 不整合面横向运移, 并逐级向高部位运移聚集于 火山岩风化体地层圈闭中成藏. 该成藏模式形成的 地层油气藏在纵向上位置比烃源岩高. 如准噶尔盆 地西北缘克-百断裂带上盘石炭系火山岩风化体大型 地层油藏, 该区受前陆盆地造山运动控制使其抬升, 推覆带前缘被推覆高度大, 经历风化淋滤时间长, 在 断裂控制下形成的风化体厚度大; 盆地边缘上覆地 层剥蚀后，火山岩经历的风化淋滤时间较短，断裂规 模较小, 形成的火山岩风化体厚度较小. 在断裂控制 


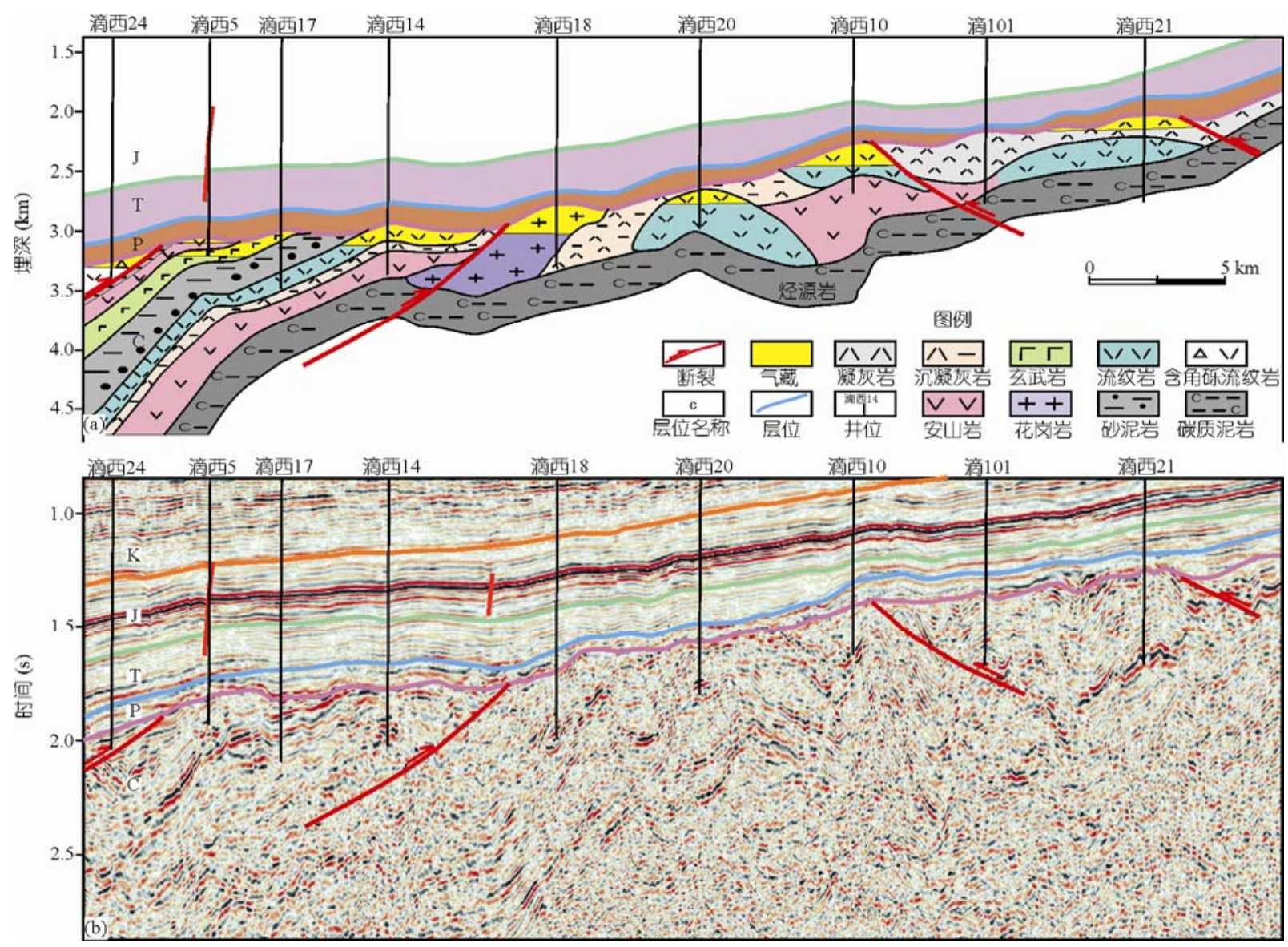

图 9 准噶尔盆地陆东地区石炭系源下火山锥准层状成藏模式

(a) 气藏剖面; (b) 地震剖面

下沿不整合面和断裂发育区形成梳状不整合风化体, 下盘二叠系烃源岩生成的油气沿断裂和不整合面逐 级向高部位运移聚集成藏, 形成大型梳状地层油藏. 该区已累计探明石油地质储量超过 2 亿多吨, 发现三 级石油地质储量超过 5 亿吨, 是中国目前发现的最大 火山岩风化体梳状地层油藏(图 10).

\section{4 结论和讨论}

(1) 新疆北部石炭系发育于陆陆碰撞和碰撞后 裂谷环境, 火山岩与烃源岩间互大面积发育, 石炭纪 之后抬升, 使火山岩暴露地表遭受风化淋滤, 形成火 山岩风化体, 之后下沉埋藏, 形成多个储盖组合, 具 备良好的油气地质条件.

（2）火山岩风化体发育 5 层结构, 溶蚀带和崩解 带储层物性最好, 与原生型火山岩相比储层物性更
好, 易形成有利储层. 在一定风化淋滤时间范围内风 化体储层厚度与风化淋滤时间成正比. 通过野外和 钻孔资料建立了火山岩风化体厚度与风化淋滤时间 的关系模型，在不受断裂控制区域可形成厚达 $450 \mathrm{~m}$ 的风化体, 在断裂发育区风化体厚度更大, 该认识拓 展了火山岩风化体勘探深度.

(3) 新疆北部石炭系发育源内火山岩层序型、源 上火山锥准层状和侧源火山岩不整合梳状 3 种成藏 模式, 断裂和风化体组成油气输导体系, 在构造相对 高部位聚集成藏. 该认识对指导火山岩风化体地层 油气藏勘探具有理论价值.

（4）火山岩风化体地层油气藏作为一种新的油 气藏类型, 开拓了油气勘探新领域, 具有重要的理论 和应用价值. 在中国针对火山岩风化体地层油气藏 勘探刚刚开始. 利用全国重磁资料结合露头和地质 调查资料, 预测位于现今盆地内部的古生界火山岩 


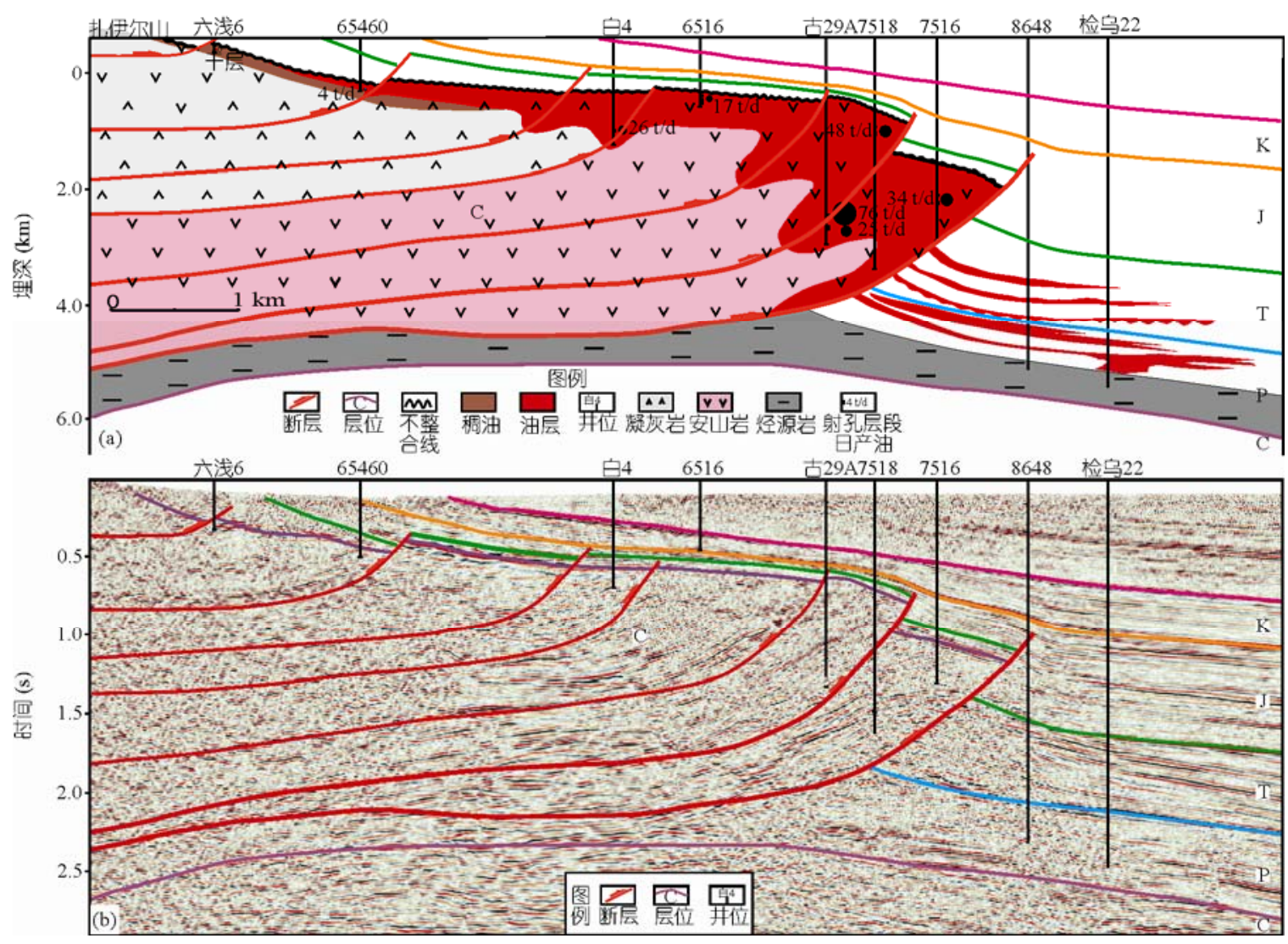

图 10 准噶尔盆地西北缘上盘石炭系侧源火山岩风化体梳状成藏模式

(a) 油藏剖面; (b) 地震剖面

面积达 $83 \times 10^{4} \mathrm{~km}^{2}$, 主要分布于新疆、川陕藏和内蒙 古等地区. 经受风化淋滤的古生界火山岩面积约为 $54 \times 10^{4} \mathrm{~km}^{2}$, 油气成藏有利面积超过 $10 \times 10^{4} \mathrm{~km}^{2}$, 这 些地区已发现油气藏或油气显示井, 具有良好的油
气地质条件, 勘探程度低, 是今后火山岩风化体地层 油气藏勘探的重点区域. 准噶尔、三塘湖、吐哈、塔 里木、四川、鄂尔多斯、伊犁和松辽等盆地是火山岩 风化体地层油气藏勘探的主要盆地.

\section{参考文献}

1 贾承造, 赵文智, 邹才能, 等. 岩性地层油气藏地质理论与勘探技术. 石油勘探与开发, 2007, 34: 257-272

2 邹才能, 陶士振. 大油气区的内涵、分类、形成和分布. 石油勘探与开发, 2007, 34: 5-12

3 邹才能, 陶士振, 谷志东. 中国低丰度大型岩性油气田形成条件和分布规律. 地质学报, 2006, 80: 1739-1751

4 林畅松, 刘景彦, 张燕梅, 等. 库车坳陷第三系构造层序的构成特征及其对前陆构造作用的响应. 中国科学 D 辑: 地球科学, 2002, 32: $177-183$

5 林畅松, 杨海军, 刘景彦, 等. 塔里木盆地古生代中央隆起带古构造地貌及其对沉积相发育分布的制约. 中国科学 D 辑: 地球科学, 2009, 39: 306-316

6 Lin C S, Eriksson K, Li S T, et al. Sequence architecture, depositional systems, and controls on development of lacustrine basin fills in part of the Erlian Basin, Northeast China. Am Assoc Petrol Geol Bull, 2001, 85: 2017-2043

7 Zhao W Z, Zou C N, Feng Z Q, et al. Geological features and evaluation techniques of deep-seated volcanics gas reserviors, Songliao Basin. Petrol Explor Dev, 2008, 35: 129-142

8 李超文, 郭锋, 范蔚若, 等. 延吉地区晚中生代火山岩的 $\mathrm{Ar}-\mathrm{Ar}$ 年代学格架及其大地构造意义. 中国科学 $\mathrm{D}$ 辑: 地球科学, 2007, 37 : 319-330 
9 袁洪林, 刘小明, 刘勇胜, 等. 北京西山中生代火山岩 U-Pb 锆石年代学及地球化学研究. 中国科学 $\mathrm{D}$ 辑: 地球科学, 2005, 35: 821-836

10 周涛发, 范裕, 袁峰, 等. 安徽卢枞(庐江-枞阳)盆地火山岩的年代学及其意义. 中国科学 D 辑: 地球科学, 2008, 38: 1342-1353

11 王剑, 付修根, 陈文西, 等. 北㒸塘沃若山地区火山岩年代学及区域地球化学对比一一对晚三叠世火山岩-沉积事件的启示. 中国科 学 D 辑: 地球科学, $2008,38: 33-43$

12 凌文黎, 谢先军, 柳小明, 等. 鲁东中生代标准剖面青山群火山岩锆石 U-Pb 年龄及其构造意义. 中国科学 D 辑: 地球科学, 2006, 36: 401-411

13 朱云海, 林启祥, 贾春兴, 等. 东昆仑造山带早古生代火山岩锆石 SHRIMP 年龄及其地质意义. 中国科学 D 辑: 地球科学, 2005, 35: 1112-1119

14 Wu C Z, Gu L X, Zhang Z Z, et al. Formation mechanisms of hydrocarbon reservoirs associated with volcanic and subervolcanic intrusive rocks: Examples in Mesozoic-Cenozoic basins of eastern China. Am Assoc Petrol Geol Bull, 2006, 90: 137-147

15 赵俊猛, 黄英, 马宗晋, 等. 准噶尔盆地北部基底结构与属性问题探讨. 地球物理学报, 2008, 51: 1767-1775

16 孟自芳, 邓云山, 丁兆海, 等. 塔里木盆地南缘中-新生代火山岩古地磁新结果. 中国科学 D 辑: 地球科学, 1998, 28: 79-89

17 吴小齐, 刘德良, 魏国奇, 等. 准噶尔盆地陆东-五彩湾地区石炭系火山岩地球化学特征及其构造背景. 岩石学报, 2009, 25: 55-66

18 李锦轶, 何国琦, 徐新, 等. 新疆北部及邻区地壳构造格架及其形成过程的初步探讨. 地质学报, 2006, 80: 148-168

19 王方正, 杨海珍, 郑建平. 准噶尔盆地陆梁地区基底火山岩的岩石地球化学及其构造环境. 岩石学报, 2002, 18: 9-16

20 王宗秀, 李涛, 周高志, 等. 博格达山晚石炭纪造山活动的变形地质记录. 地学前缘, 2003, 10: 63-69

21 陈博, 朱永峰, 魏少妮, 等. 西准噶尔克拉玛依蛇绿混杂岩中的石榴角闪岩. 岩石学报, 2008, 24: 1034-1040

22 雷敏, 赵志丹, 侯青叶, 等. 新疆达拉布特蛇绿岩带玄武岩地球化学特征: 古亚洲洋与特提斯洋的对比. 岩石学报, 2008, 24: 661-672

23 马林, 张海祥, 张伯友, 等. 新疆北部库尔提蛇绿岩中角闪片岩的原岩恢复及其成因. 岩石学报, 2008, 24: 673-680

24 刘希军, 许继峰, 侯青叶, 等. 新疆东准噶尔克拉麦里蛇绿岩地球化学: 洋脊俯冲的产物. 岩石学报, 2008, 23: 1591-1602

25 徐学义, 李向民, 马中平, 等. 北天山巴音沟蛇绿岩形成于早石炭世: 来自辉长岩 LA-ICPMS 铅石 U-Pb 年龄的证据. 地质学报, 2006, 80: 1168-1176

26 肖文交, Windley B F, 阎全人, 等. 北疆地区阿尔曼太蛇绿岩锆石 SHRIMP 年龄及其大地构造意义. 地质学报, 2006, 80: 32-37

27 Pearce J A. Some relationships between the geochemistry and tectonic setting of volcanic rocks. Doctoral Thesis. Norwich: University of East Anglia, 1973

28 冯子辉, 邵红梅, 童英. 松辽盆地庆深气田深层火山岩储集层控制因素研究. 地质学报, 2008, 82: 760-768

29 Le Maitre R W, Bateman P, Dudek A, et al. A Classification of Igneous Rocks and Glossary of terms: Recommendations of the International Union of Geological Sciences Subcommission on the Systematics of Igneous Rocks. Oxford: Blackwell Scientific Publications, 1989

30 Furnes H, Muehlenbachs K, Tumyr O, et al. Biogenic alteration of volcanic glass from the Troodos ophiolite, Cyprus. J Geol Soc London, 2001, 158: 75-84

31 Figlia M G, Bellanca A, Neri R, et al. Chemical weathering of volcanic rocks at the island of Pantelleria, Italy: Information from soil and soil solution investigations. Chem Geol, 2007, 246: 1-18

32 Setphens J C, Hering J G. Factors affecting the dissolution kinetics of volcanic ash soils: Dependencies on $\mathrm{pH}, \mathrm{CO}_{2}$, and oxalate. Appl Geochem, 2004, 19: 1217-1232

33 Han Y, Huh Y. A geochemical reconnaissance of the Duman (Tumen) River and the hot springs of Mt. Baekdu (Changbei): Weathering of volcanic rocks in mid-latitude setting. Chem Geol, 2009, 264: 162-172

34 Goldsmith S T, Carey A E, Lyons W B, et al. Geochemical fluxes and weathering of volcanic terrains on high standing islands: Taranaki and Manawatu-Wanganui regions of New Zealand. Geochim Cosmochim Acta, 2008, 72: 2248-2267

35 Weijers L, Griffin L G, Sugiyama H, et al. Hydraulic fracturing in a deep, naturally fractured volcanic rock in Japan design considerations and execution results. SPE77823 presented at the 2002 SPE Asia Pacific Oil and Gas Conference and Exhibition held in Melbourne, Australia, 8-10 October, 2002

36 Yamada T, Okano Y. A volcanic reservoir: Facies distribution model accounting for pressure communication. SPE93159 presented at the 2005 Asia Pacific Oil and Gas Conference and Exhibition held in Jakatra, Indonesia, 5-7 April, 2005

37 Sruoga P, Rubinstein N, Hinterwimmer G. Porosity and permeability in volcanic rocks: A case study on the Serie Tobifera, South Patagonia, Argentina. J Volcanol Geoth Res, 2004, 132: 31-43

38 Tang H, Ji H C. Incorporation of spatial characters into volcanic facies and favorable reservoir prediction. SPE90847 presented at the 2004 
SPE Annual Technical Conference and Exhibition held in Houston, Taxas, U.S.A, 26-29 September, 2004

39 Luo J L, Morad S, Liang Z Z, et al. Controls on the quality of archean metamorphic and Jurassic volcanic reservoir rocks from the Xinglongtai buried hill, western depression of Liaohe Basin, China. Am Assoc Petrol Geol Bull, 2005, 89: 1319-1346

40 侯连华, 邹才能, 匡立春, 等. 准噶尔盆地西北缘克-百断裂带石炭系油气成藏控制因素新认识. 石油学报, 2009, 30: 513-517

41 张丽萍, 杨达源, 朱大奎. 长江三峡黄陵背斜段地质时期结晶岩风化剥蚀速率研究. 中国科学 D 辑: 地球科学, 2003, 33: 81-88

42 李勇, 黎兵. 剥蚀-沉积体系中剥蚀量与沉积通量的定量对比研究一以岷江流域为例. 地质学报, 2007, 81: 332-343

43 Rohrman M. Prospectivity of volcanic basins: Trap delineation and acreage de-risking. Am Assoc Petrol Geol Bull, 2007, 91: 915-939

44 Colman S M, Pierce K L. Weathering rinds on andesitic and basaltic stones as a Quaternary age indicator, Western United States. US Geol Surv Prof Pap, 1980, 1210: 1-56

45 Whitehouse J E, McSaveney M J, Chinn T J H, et al. Growth of weathering rinds on Torlesse sandstone, Southern Alps, New Zealand. In: Colman S M, Dethier D P, eds. Rates of Chemical Weathering of Rocks and Minerals. Orlando: Academic Press, 1986. 419-435

46 李保俊, 杨景春, 李有利, 等. 根据砾石风化圈厚度估算地貌年龄. 地理研究, 1996, 15: 11-21

47 李案阳, 梁风. 碳酸盐岩红土风化剖面的淋滤试验研究—以贵州遵义和平坝剖面为例. 中国岩溶, 2001, 20: 167-173

48 Zhao W Z, Zou C N, Li J Z, et al. Comparative study on volcanic hydrocarbon accumulations in western and eastern China and its significance. Petrol Explor Dev, 2009, 36: 1-11 